\title{
Mutational diversity and hot spots in the $\alpha$-sarcoglycan gene in autosomal recessive muscular dystrophy (LGMD2D)
}

A Carrié, F Piccolo, F Leturcq, C de Toma, K Azibi, C Beldjord, J-M Vallat, L Merlini, T Voit, C Sewry, J A Urtizberea, N Romero, F M S Tomé, M Fardeau, Y Sunada, K P Campbell, J-C Kaplan, M Jeanpierre

INSERM 129 and

Hôpital Cochin,

Université Paris V,

Paris, France

A Carrié

F Piccolo

F Leturcq

$\mathrm{C}$ de Toma

K Azibi

C Beldjord

J-C Kaplan

$M$ Jeanpierre

CHU Bologhine,

Algiers, Algeria

K Azibi

Service de Neurologie, Limoges, France

$\mathrm{J}-\mathrm{M}$ Vallat

Istituto Ortopedico

Rizzoli, Bologna, Italy

L Merlini

Department of

Paediatrics, Essen,

Germany

$\mathrm{T}$ Voit

Hammersmith

Hospital, London, UK

C Sewry

Myobank, AFM, Evry,

France

J A Urtizberea

Hôpital Robert Debré, Paris, France

N Romero

INSERM 153, Institut de Myologie, Hôpital Pitié-Salpêtrière,

Paris, France

F M S Tome

M Fardeau

University of Iowa College of Medicine, Iowa City, USA

$Y$ Sunada

K P Campbell

Correspondence to: Dr Kaplan, Laboratoire de Biochimie et Génétique Moléculaire, Hôpital Cochin, 24 rue du Faubourg

St-Jacques, 75014 Paris, France.

Received 29 November 1996 Revised version accepted for publication 5 March 1997

\begin{abstract}
Sarcoglycanopathies are a genetically heterogeneous group of autosomal recessive muscular dystrophies in which the primary defect may reside in any of the genes coding for the different partners of the sarcolemmal sarcoglycan (SG) complex: the $\alpha$-SG (LGMD2D at 17q21.2), the $\beta$-SG (LGMD2E at 4q12), the $\gamma$-SG (LGMD2C at 13q12), and the $\delta$-SG (LGMD2F at 5q33). We report a series of 20 new unrelated families with 14 different mutations in the $\alpha-S G$ gene. Along with the mutations that we previously reported this brings our cohort of patients with $\alpha$-sarcoglycanopathy to a total of 31 unrelated patients, carrying 25 different mutations. The missense mutations reside in the extracellular domain of the protein. Five of 15 missense mutations, carried by unrelated subjects on different haplotype backgrounds and of widespread geographical origins, account for $58 \%$ of the mutated chromosomes, with a striking prevalence of the $R 77 \mathrm{C}$ substitution $(32 \%)$. The severity of the disease varies strikingly and correlates at least in part with the amount of residual protein and the type of mutation. The recurrent R284C substitution is associated with a benign disease course.

(F Med Genet 1997;34:470-475)
\end{abstract}

Keywords: $\alpha$-sarcoglycan gene; muscular dystrophy; LGMD2D

Alpha-sarcoglycan, previously called adhalin, ${ }^{1}{ }^{2}$ is the $50 \mathrm{kDa}$ component of the dystrophin connected sarcolemmal sarcoglycan (SG) complex. ${ }^{34}$ This protein has been shown to be deficient in severe childhood autosomal recessive muscular dystrophy (SCARMD), ${ }^{56}$ a Duchenne-like disease affecting both males and females, which sometimes overlaps clinically with the less severe limb-girdle muscular dystrophy (LGMD). ${ }^{7}$ Alpha-sarcoglycan deficiency is genetically heterogeneous. ${ }^{89}$ It may result from primary defects in the $\alpha$-sarcoglycan gene itself (LGMD2D at $17 \mathrm{q} 21.2)^{10-12}$ or be secondary to defects involving other SG genes: $\beta$-SG at LGMD2E $(4 \mathrm{q} 12),{ }^{13}{ }^{14} \gamma$-SG at LGMD2C (13q12), ${ }^{15}$ and $\delta$-SG at LGMD2F (5q33). ${ }^{16}$ Several different mutations in the $\alpha$-SG gene have already been reported by us ${ }^{10}{ }^{11}$ and others ${ }^{17-19}$ in geographically widespread families. In this study we report an additional series of 20 unrelated LGMD families with primary $\alpha$-sarcoglycanopathy (LGMD2D), carrying 12 novel mutations in the $\alpha-S G$ gene. From our cumulative collection of 25 different mutations in the $\alpha$-SG gene, it now appears that (1) there are preferential sites (exon 3) and types (R77C, R284C) of mutations; (2) the 15 different missense mutations, exclusively located in the extracellular domain of the protein, result in variable decrease of the protein without drastically affecting the level of transcripts; (3) the severity of disease may be at least in part correlated with the genotype; and (4) there is no geographical restriction of LGMD2D.

\section{Patients and methods}

SUBJECTS AND CLINICAL STUDIES

Peripheral blood samples were obtained from patients and relatives in 51 unrelated families in which $\alpha$-sarcoglycan deficiency had been ascertained by immunofluorescence or western blotting or both. ${ }^{11}$ All patients but patients 6571 and 6710 presented with a limb-girdle muscular dystrophy phenotype of variable severity. Noteworthy are the absence of heart involvement and mental retardation. The full clinical presentation of patients with a mutated $\alpha$-sarcoglycan gene in 15 families is given in Eymard et al..$^{20}$

Patient 6571, a female of French ancestry, was born in 1940 to unrelated parents. At the age of 54 she underwent a muscle biopsy to elucidate recurrent myositis-like episodes with raised serum creatine kinase activity. She complained of weakness but without a real impact on her physical activity. No muscle deficit was observed. Muscle biopsy showed unobtrusive muscular dystrophy alterations and $\alpha$-sarcoglycan reduction.

Patient 6710, a female born in 1968 to related parents of North African origin, was found at the age of 24 to have a raised serum transaminase level during a routine occupational medicine check up. She complained of some tiredness in her professional activity (office worker) but was found to be normal on clinical examination by an experienced neurologist. Since serum creatine kinase was found to be repeatedly raised (700-2000 IU), a muscle biopsy was performed, showing limited muscular dystrophy alterations and marked $a$-sarcoglycan reduction. 
Table 1 Parameters for amplification of the a-sarcoglycan gene fragments and DGGE conditions

\begin{tabular}{|c|c|c|c|c|c|c|}
\hline Fragment & Sequences of primers ${ }^{\star}$ & $\begin{array}{l}\text { Length } \\
(b p)\end{array}$ & $\begin{array}{l}\text { Annealing } \\
\text { temp }\left({ }^{\circ} \mathrm{C}\right)\end{array}$ & & $\begin{array}{l}\text { Gradient } \\
(\%)\end{array}$ & $\begin{array}{l}\text { Running time } \\
\text { (h) at } 160 v\end{array}$ \\
\hline Exon 1 & $\begin{array}{l}\text { 1F: 5'-CCTGTCTCTGTCACTCACCG-3' } \\
\text { 1R: 5' Pso-AATCCTGCCCCCTCATCCTGG-3' }\end{array}$ & 128 & 60 & & $40-90$ & 7.5 \\
\hline Exon 2 & $\begin{array}{l}\text { 2F: 5'-GCCTGTGTGTTTGGGACTTG-3' } \\
\text { 2R: 5' Pso-AATACACCCCAGCCCGCCCGCC-3' }\end{array}$ & 197 & 60 & & $40-90$ & 6.5 \\
\hline Exon 3 & $\begin{array}{l}\text { 3F: 5'-GGGCTCCTGCTGTGACTCGA-3' } \\
\text { 3R: 5' Pso-AATGGCCCACCCCTGTGATTTT-3' }\end{array}$ & 239 & 58 & & $50-90$ & 9.0 \\
\hline Exon 4 & $\begin{array}{l}\text { 4F: 5' Pso-AATTTCTCCCCTAACCCACTTC-3' } \\
\text { 4R: 5'-AAGACTGGCATTGGTGGGGA-3' }\end{array}$ & 162 & 60 & & $40-90$ & 7.5 \\
\hline Exon 5 & $\begin{array}{l}\text { 5F: 5' Pso-AAGCAGGGATGTGGGGAGGAGC-3' } \\
\text { 5R: 5'-AGTCCTCTAGGGTTGCACAC-3' }\end{array}$ & 311 & 58 & & $40-90$ & 13.0 \\
\hline \multirow[t]{2}{*}{ Exon 6} & 6F: 5'-CTGCCCCCACTCTGCTGACA-3' & 444 & 59 & $\begin{array}{l}\text { Lowest } \\
\text { melting } \\
\text { domain }\end{array}$ & $30-80$ & 8.5 \\
\hline & 6R: 5' Pso-AAGGGAAGGGGGACTGGGATGG-3' & & & $\begin{array}{l}\text { Highest } \\
\text { melting } \\
\text { domain } \dagger\end{array}$ & 40-90 & 9.0 \\
\hline Exon 7 & $\begin{array}{l}\text { 7F: 5'-TGTCCAGCCAGCCACTTCCT-3' } \\
\text { 7R: 5' Pso-AATCCCATACAGACAAGTGCCA-3' }\end{array}$ & 339 & 58 & & $40-90$ & 11.0 \\
\hline Exon 8 & $\begin{array}{l}\text { 8F: 5' Pso-AAGGGCACCTTGGGGCGAAACC-3' } \\
\text { 8R: 5'-ATAGTTTGGTGGCGGGGTCC-3' }\end{array}$ & 152 & 60 & & $30-80$ & 6.5 \\
\hline
\end{tabular}

${ }^{\star}$ Intronic primers of the $\alpha$-sarcoglycan gene (unpublished data).

tHigher melting domain was investigated after $M b o$ II digestion.

IMMUNOSTAINING OF CRYOSECTIONS AND

IMMUNOBLOT ANALYSIS

Muscle biopsies were processed as described by Piccolo et $a l^{11}$ using monoclonal antibodies against dystrophin (DYS $1^{\mathrm{k}}$, DYS2 ${ }^{\mathrm{k}}$, Novocastra, Newcastle, UK), $\alpha-S G$ (adhalin, NCL50DAG, Novocastra, Newcastle, UK), and $\gamma$-SG (21B5, personal gift from L Anderson).

\section{MUTATION ANALYSIS}

Denaturing gradient gel electrophoresis (DGGE)

The first eight exons and the 20-30 bp long flanking intronic sequences of the $\alpha$-SG gene were separately PCR amplified from genomic DNA using primers listed in table 1 , with psoralen clamps. ${ }^{21}$ DGGE conditions were chosen

Table 2 The cumulative spectrum of null mutations in the a-sarcoglycan gene

\begin{tabular}{|c|c|c|c|c|c|c|}
\hline $\begin{array}{l}\text { Mutation } \\
\text { type }\end{array}$ & $\begin{array}{l}\text { Position } \\
\text { in the } \\
\text { gene }\end{array}$ & Mutation & $\begin{array}{l}\text { Restriction } \\
\text { site }\end{array}$ & $\begin{array}{l}\text { Patient } \\
\text { code }\end{array}$ & $\begin{array}{l}\text { Geographical } \\
\text { origin }\end{array}$ & Consequence \\
\hline \multirow[t]{2}{*}{ Nonsense } & $\begin{array}{l}\text { Exon } 3 \\
\text { (codon } \\
80 \text { ) }\end{array}$ & $\mathrm{CAG} \rightarrow \mathrm{TAG} \dagger$ & None & 6379 & France & $Q(80) X$ \\
\hline & $\begin{array}{l}\text { Exon } 5 \\
\text { (codon } \\
151 \text { ) }\end{array}$ & $\mathrm{TCA} \rightarrow \mathrm{TGA} \dagger$ & None & 6425 & Italy & $S(151) X$ \\
\hline \multirow[t]{4}{*}{ Frameshift } & $\begin{array}{l}\text { Exon } 3 \\
\text { nt } 161 \\
\text { (codon } \\
54 \text { ) }\end{array}$ & del T & None & 6623 & Morocco & $\begin{array}{l}\text { Premature stop } \\
\text { after } 66 \text { aberrant } \\
\text { codons }\end{array}$ \\
\hline & $\begin{array}{l}\text { Exon } 5 \\
\text { nt } 411 \\
\text { (codon } \\
137 \text { ) }\end{array}$ & dupl $8 \mathrm{nt} \dagger$ & None & 6324 & Morocco & $\begin{array}{l}\text { Premature stop } \\
\text { after } 135 \text { aberrant } \\
\text { codons }\end{array}$ \\
\hline & $\begin{array}{l}\text { Exon } 7 \\
\text { nt } \\
754- \\
755 \\
\text { (codon } \\
252 \text { ) }\end{array}$ & del AA & None & 6456 & France & $\begin{array}{l}\text { Premature stop } \\
\text { after } 7 \text { aberrant } \\
\text { codons }\end{array}$ \\
\hline & $\begin{array}{l}\text { Exon } 8 \\
\text { nt } 964 \\
\text { (codon } \\
322)\end{array}$ & del AG & None & 6620 & USA & $\begin{array}{l}\text { Premature stop } \\
\text { after } 47 \text { aberrant } \\
\text { codons }\end{array}$ \\
\hline \multirow[t]{4}{*}{ Splice } & $\begin{array}{l}\text { Intron } 1 \\
+3\end{array}$ & $\mathrm{~A} \rightarrow \mathrm{T}$ & MaeI + & 6280 & Algeria & Aberrant splicing \\
\hline & $\begin{array}{l}\text { Intron } 6 \\
-1\end{array}$ & $\mathrm{G} \rightarrow \mathrm{A} \dagger$ & BspmI - & 6141 & Algeria & Aberrant splicing \\
\hline & $\begin{array}{l}\text { Intron } 7 \\
-1\end{array}$ & $\mathrm{G} \rightarrow \mathrm{T} \dagger$ & NlaIII + & 6393 & France & Aberrant splicing \\
\hline & $\begin{array}{l}\text { Intron } 7 \\
+2\end{array}$ & $\mathrm{~T} \rightarrow \mathrm{C}$ & $H_{p h \mathrm{I}-}$ & 6505 & GB & Aberrant splicing \\
\hline
\end{tabular}

${ }^{\star}$ nt position in the cDNA sequence (Genbank HSU08895) starting from the initial ATG. †Mutation reported in a previous series. "I according to the Meltmap program..$^{22}$ The presence of two melting domains in exon 6 required a two step analysis: the lowest melting domain was directly analysed in the entire PCR product and the highest melting domain was investigated after $M b o$ II digestion (table 1 ).

\section{Mutation identification}

PCR products showing an abnormal migration pattern on DGGE analysis were directly sequenced on an automated sequencer (ABI 377, Perkin-Elmer) using the DyeTerminator method. Every sequence variation was checked by restriction analysis of genomic DNA (tables 2 and 3) or by allele specific oligoprobe hybridisation. Familial segregation was also checked. Owing to the recurrence of some mutations we routinely ran side by side the sample under investigation and the already characterised mutated exons serving as references. In case of an identical pattern, the exon under investigation was mixed with the reference amplicons and rerun on DGGE. The absence of new heteroduplex indicated that the two samples carried identical mutations.

TRANSCRIPT ANALYSIS

Total RNA was extracted from muscle biopsy specimens by RNAzol (Bioprobe) according to the manufacturer's protocol. RT-PCR was performed on $4 \mu \mathrm{g}$ of total RNA from muscle generating three overlapping fragments of $\alpha$-sarcoglycan cDNA:

fragment 1: 5' CCGTGTCTTTGTGCACACCTTGGA $3^{\prime}$ and 5' CAAGGCTGAGAGGAAGCGGCTGGCA 3';

fragment 2: 5' CCGCTTCCTCTCAGCCTTGG 3' and 5' GGGAGGCAGCCGCTCACCTGTG 3';

fragment 3: 5' AACACAGAGGAGCTGCGG 3 ' and 5' TGTGGACAGAGAAGGGAGGATG 3'.

GAPDH mRNA was coamplified as an internal control in quantitative RT-PCR ( $5^{\prime}$ GGGAGATTCAGTGTGGTGGG $3^{\prime}$ and $5^{\prime}$ CGGGGCTCTCCAGAACATCA 3'). PCR conditions were as follows: hot start after five minutes at $80^{\circ} \mathrm{C}, 60^{\circ} \mathrm{C}$ for one minute, and 45 
Table 3 The cumulative spectrum of missense mutations in the a-sarcoglycan gene

\begin{tabular}{|c|c|c|c|c|}
\hline $\begin{array}{l}\text { Mutation and position in } \\
c D N A^{\star}\end{array}$ & $\begin{array}{l}\text { Consequence in the } \\
\text { protein sequence } \\
\text { (extracellular } \\
\text { domain) }\end{array}$ & $\begin{array}{l}\text { No of unrelated } \\
\text { chromosomes }\end{array}$ & $\begin{array}{l}\text { Restriction } \\
\text { site }\end{array}$ & $\begin{array}{l}\text { Geographical } \\
\text { origin } \neq\end{array}$ \\
\hline \multicolumn{5}{|l|}{ Exon 2} \\
\hline $\mathrm{CCA} \rightarrow \mathrm{CTA}$ nt 89 & $\mathrm{P}(30) \mathrm{L}$ & 1 & None & G \\
\hline CGT $\rightarrow$ TGT nt 100 & $\mathrm{R}(34) \mathrm{C}$ & 1 & HaeIII - & Alg \\
\hline CGT $\rightarrow$ CAT nt 101 & $\mathbf{R}(34) \mathbf{H} \dagger$ & 3 & NlaIII + & $\mathrm{F}, \mathrm{I}, \mathrm{US}$ \\
\hline \multicolumn{5}{|l|}{ Exon 3} \\
\hline TAC $\rightarrow$ CAC nt 187 & $\mathrm{Y}(62) \mathrm{H} \dagger$ & 1 & None & $\mathbf{F}$ \\
\hline GGA $\rightarrow$ GAA nt 206 & $\mathrm{G}(68) \mathrm{Q} \dagger$ & 1 & BsmFI - & F \\
\hline $\mathrm{CGC} \rightarrow \mathrm{TGC}$ nt 232 & $\mathbf{R}(77) \mathbf{C}+$ & 15 & $\begin{array}{l}\text { NlaIV - } \\
\text { AciI - }\end{array}$ & $\begin{array}{l}F(8), G(2), S p, \\
U S(4)\end{array}$ \\
\hline GGC $\rightarrow$ CGC nt 270 & $\mathrm{G}(91) \mathrm{R}$ & 1 & $B s r \mathrm{BI}+$ & I \\
\hline $\begin{array}{l}\text { CGT } \rightarrow \text { CAT nt } 295 \\
\text { Exon } 4\end{array}$ & $\mathbf{R}(\mathbf{9 8}) \mathbf{H} \dagger$ & 2 & NlaIII + & $\mathrm{F}, \mathrm{Sp}$ \\
\hline $\begin{array}{l}\text { ATT } \rightarrow \text { ACT nt } 371 \\
\text { Exon } 5\end{array}$ & $\mathrm{I}(124) \mathrm{T}$ & 1 & $B s r I+$ & US \\
\hline GAG $\rightarrow$ AAG nt 409 & $\mathrm{E}(137) \mathrm{K}$ & 1 & $B s t \mathrm{XI}+$ & I \\
\hline CTC $\rightarrow$ CCC nt 521 & $\mathrm{~L}(173) \mathrm{P}$ & 1 & None & GB \\
\hline $\begin{array}{l}\text { GTC } \rightarrow \text { GCC nt } 527 \\
\text { Exon } 6\end{array}$ & $\mathrm{~V}(175) \mathrm{A} \uparrow$ & 1 & HphI - & $\mathrm{F}$ \\
\hline GTT $\rightarrow$ GCT nt 728 & $\mathrm{~V}(242) \mathrm{A} \dagger$ & 1 & HhaI + & $\mathrm{F}$ \\
\hline $\begin{array}{l}\text { GTG } \rightarrow \text { ATG nt } 742 \\
\text { Exon } 7\end{array}$ & $\mathbf{V}(\mathbf{2 4 7}) \mathbf{M} \dagger$ & 2 & $B s r \mathrm{DI}-$ & $\mathrm{F}, \mathrm{I}$ \\
\hline $\mathrm{CGT} \rightarrow \mathrm{TGT}$ nt 850 & $\mathbf{R}(284) \mathbf{C}$ & 6 & None & $F(4), I(2)$, Mor \\
\hline
\end{tabular}

Bold type: recurrent mutations.

${ }^{*}$ nt position in the cDNA sequence (Genbank HSU08895) starting from the initial ATG

†Mutation reported in a previous series. ${ }^{11}$

$\ddagger$ Numbers in parentheses indicate the number (when $>1$ ) of unrelated patients with the same mutation in a given country (F: France, G: Germany, GB: Great Britain, I: Italy, Sp: Spain, Alg: Algeria, Mor: Morocco).

Table 4 Hot spots for recurrent missense mutations in the a-sarcoglycan gene

\begin{tabular}{|c|c|c|c|c|c|}
\hline $\begin{array}{l}\text { Position of } \\
\text { codon }\end{array}$ & Mutation & Missense & $\begin{array}{l}\text { No of } \\
\text { independent } \\
\text { chromosomes } \\
\text { carrying the } \\
\text { mutation in } \\
\text { our series }\end{array}$ & $\begin{array}{l}\% \text { of total No } \\
\text { of independent } \\
\text { mutated } \\
\text { chromosomes * } \\
(n=49)\end{array}$ & References \\
\hline \multicolumn{6}{|l|}{ CpG } \\
\hline 77 & $\mathrm{CGC} \rightarrow \mathrm{TGC}$ & $\mathrm{R} \rightarrow \mathrm{C}$ & 15 & 31 & $\begin{array}{l}3 \text { families (ref 19) } \\
1 \text { family (ref 18) }\end{array}$ \\
\hline 284 & $\mathrm{CGT} \rightarrow \mathrm{TGT}$ & $\mathrm{R} \rightarrow \mathrm{C}$ & 6 & 12 & \\
\hline \multirow[t]{2}{*}{34} & $\mathrm{CGT} \rightarrow \mathrm{TGT}$ & $\mathrm{R} \rightarrow \mathrm{H}$ & 3 & 8 & \\
\hline & $\mathrm{CGT} \rightarrow$ CAT & $\mathrm{R} \rightarrow \mathrm{C}$ & 1 & & \\
\hline 98 & $\mathrm{CGT} \rightarrow \mathrm{TGT}$ & $\mathrm{R} \rightarrow \mathrm{H}$ & 2 & 4 & $\begin{array}{l}1 \text { family with } \\
\text { CGT } \rightarrow \text { TGT (R98H) } \\
\text { CGT } \rightarrow \text { CAT (R98C) } \\
(\text { ref 17) }\end{array}$ \\
\hline \multicolumn{6}{|l|}{ Non-CpG } \\
\hline 247 & GTG $\rightarrow$ ATG & $\mathrm{V} \rightarrow \mathrm{M}$ & 2 & 4 & \\
\hline
\end{tabular}

^Assuming that all homozygotes have two identical chromosomes by descent.

seconds at $72^{\circ} \mathrm{C}, 45$ seconds at $94^{\circ} \mathrm{C}, 45$ seconds at $60^{\circ} \mathrm{C}$ for 35 cycles, with a final elongation for two minutes at $72{ }^{\circ} \mathrm{C}$. Transcripts with abnormal size were purified from the gel and sequenced using the same PCR primers.

\section{Results}

\section{MUTATIONS}

The first eight exons of the $\alpha$-SG gene and their flanking intronic sequences were scanned by DGGE analysis in 51 unrelated families with male and female LGMD patients with $\alpha$-sarcoglycan deficiency and normal or near normal dystrophin levels. We found the $\alpha$-sarcoglycan gene mutated in 20 families of widespread geographical origin (France, UK, Italy, Germany, Spain, North Africa, USA). Nine unrelated patients were homozygous and 11 were compound heterozygotes. In all compound heterozygotes but one, both mutations were identified. A total of 14 different mutations were observed: five novel null mutations (nonsense, frameshift, or splice) and nine missense mutations of which two ( $\mathrm{R} 34 \mathrm{H}$ and R77C) had already been described in our previous report. ${ }^{11}$ In this series, 26 of the 40 mutated chromosomes carried a missense mutation observed more than once in unrelated families. None of these mutations was found in 200 control chromosomes. In tables 2 and 3 and in fig 1 we give a cumulative tabulation of the 25 different mutations in the $\alpha-S G$ gene that we have observed to date, including the 13 that we previously reported. ${ }^{11}$ In this tabulation the mutations are split into two categories: 10 null mutations (two nonsense, four frameshifts, four splice) of which none was recurrent (table 2, fig 1) and 15 missense mutations (table 3 , fig 1) of which five were recurrent (table 4). During this survey (covering 128 chromosomes altogether) four rare, possibly neutral, sequence variations were found: intron $1+27 \quad \mathrm{G} \rightarrow \mathrm{A} \quad(\mathrm{AclI}-)$ on six chromosomes; exon $5 \mathrm{ACC} \rightarrow \mathrm{ACT}=\mathrm{T}(176) \mathrm{T}$ (HphI-) on one chromosome; exon 7 $\mathrm{CTC} \rightarrow \mathrm{CTT}=\mathrm{V}(311) \mathrm{V}(\mathrm{NlaIII}+)$ on 15 chromosomes; 3'UTR $\mathrm{C} \rightarrow \mathrm{T}$ nt1233 on one chromosome.

\section{TRANSCRIPTS}

For six LGMD patients, muscle biopsies were available for transcript analysis (patients 6141, $6280,6379,6487,6556$, and 6587). Alphasarcoglycan muscular transcripts, analysed by RT-PCR from normal muscle, showed the full length and two alternative splicing forms. Sequence analysis of the shorter forms showed that the first one is similar to that already reported by McNally et al. ${ }^{23}$ It is still in frame and corresponds to the splicing of exons 6 and 7 (not shown). The second one is out of frame because it corresponds to the skipping of the 155 bp long exon 3 (not shown). RT-PCR from patients showed the three $\alpha$-SG transcript forms at normal or slightly reduced levels, except for subjects carrying a homozygous splicing mutation (patients 6141 and 6280 , see discussion).

PROTEINS

Analysis by IF and western blotting of the $\alpha$ and $\gamma$-SG proteins in patient muscle specimens showed a significant decrease, of variable degrees from patient to patient, but the decrease of $\alpha$-SG was consistently more pronounced (tables 5 and 6 ).

\section{Discussion}

In a previous study we had analysed 13 independent patients with normal dystrophin and deficient adhalin (now $\alpha-S G$ ). In this first series, 11 cases were classified as primary adhalinopathies because the $\alpha$-SG gene itself was mutated, with altogether five different null and eight different missense mutations. ${ }^{11}$ In the present series we investigated 51 new families out of which 20 families were found to harbour mutations in the $\alpha$-SG gene, with 12 additional novel mutations (five null and seven missense) (tables 2 and 3). It has now become possible to have a broad view of the molecular pathology of the $\alpha$-SG gene and its consequences. 
Null

mutations

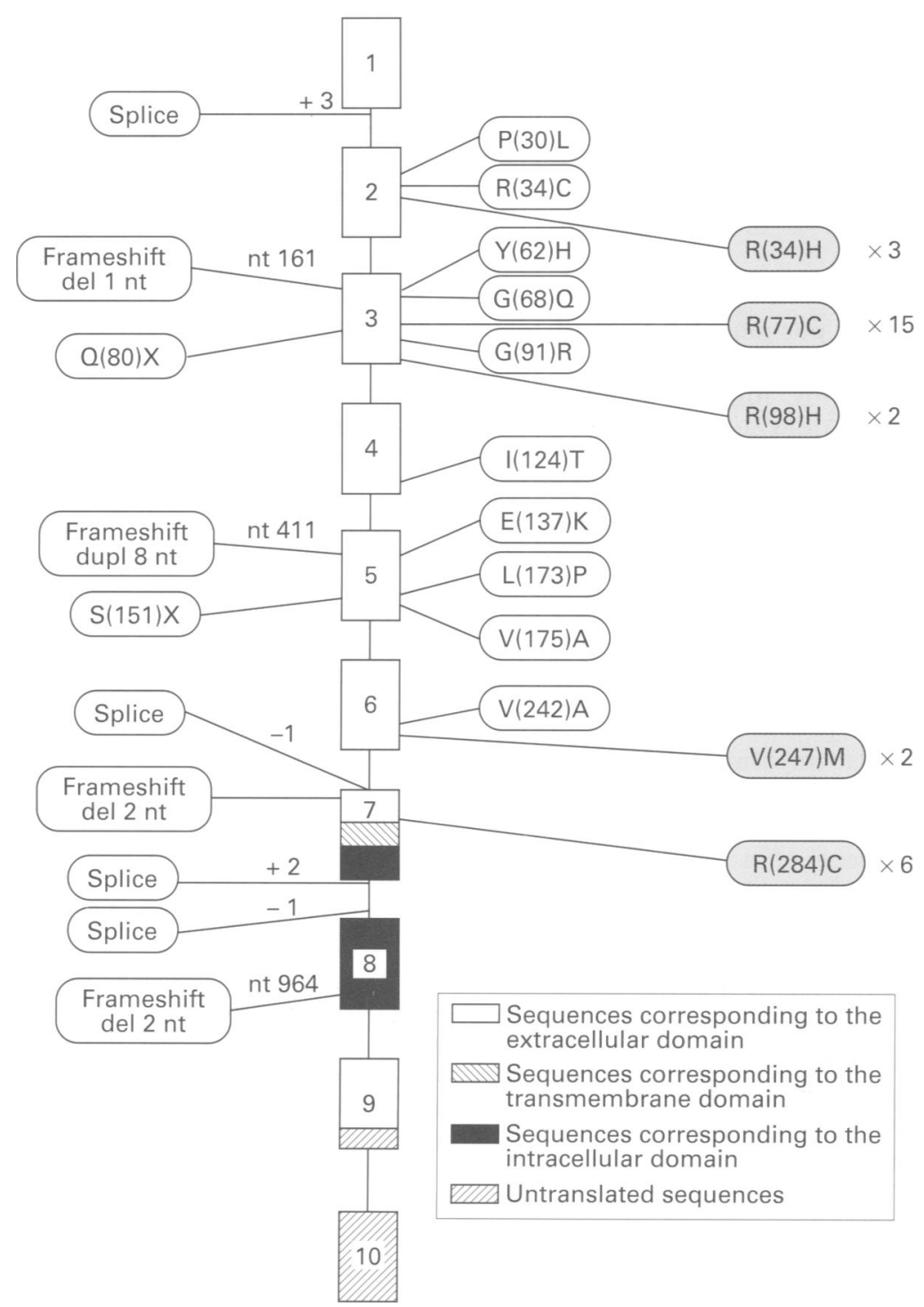

Figure 1 Positions of mutations in the a-sarcoglycan gene. Recurrent mutations are shaded with number of independent cases observed.

Table 5 Phenotype/genotype correlations in homozygotes

\begin{tabular}{|c|c|c|c|c|}
\hline Phenotype & Patients & $\begin{array}{l}\text { Homozygous } \\
\text { mutation }\end{array}$ & $a-S G$ & $\gamma-S G$ \\
\hline \multicolumn{5}{|l|}{ Severe } \\
\hline & 6623 & Splice & nd & nd \\
\hline & 6324 & Frameshift & nd & nd \\
\hline & 6280 & Splice & $0^{\mathrm{WB} B}$ & $+{ }^{W B}$ \\
\hline & 6141 & Splice & $0^{\mathrm{W} B \mathrm{~B}}$ & $++^{W B}$ \\
\hline & 6495 & $\mathrm{R}(34) \mathrm{C}$ & $0^{\mathrm{wBB}}$ & $+W^{W B}$ \\
\hline \multicolumn{5}{|c|}{ Intermediate } \\
\hline & 6421 & $\mathrm{R}(34) \mathrm{H}$ & $0^{\mathrm{WB}}$ & nd \\
\hline & 6520 & $\mathrm{R}(77) \mathrm{C}$ & $0^{\mathrm{IF}}$ & $0^{\mathrm{IF}}$ \\
\hline & 6604 & $\mathrm{R}(77) \mathrm{C}$ & nd & nd \\
\hline & 6609 & $\mathrm{R}(77) \mathrm{C}$ & nd & nd \\
\hline \multicolumn{5}{|l|}{ Moderate } \\
\hline \multirow{3}{*}{ Benign } & 6516 & $\mathrm{R}(77) \mathrm{C}$ & nd & nd \\
\hline & 6571 & $\mathrm{R}(284) \mathrm{C}$ & $++^{\mathrm{IF}}+{ }^{\mathrm{WB}}$ & $+++{ }^{W B}$ \\
\hline & 6710 & $\mathrm{R}(284) \mathrm{C}$ & $++^{\mathrm{WB}}$ & $+++{ }^{\mathrm{WB}}$ \\
\hline
\end{tabular}

nd: not done.

${ }_{\text {WB }}$ : by western blot (normal signal $=+++$ )

$\mathrm{IF}$ : by immunofluorescence (normal signal $=+++$ ).

In the first place it is clear that among dystrophin normal/ $\alpha-S G$ deficient patients, LGMD2D is not a rare condition. Our cohort of 31 independent families was obtained by systematic analysis of a series of 64 unrelated patients selected on the following criteria: (1) proximal muscle dystrophy of variable severity, (2) normal dystrophin, and (3) absence or reduced amount of $\alpha$-sarcoglycan. Although this high proportion of patients with a primary defect of the $\alpha$-SG may be partly attributed to the efficiency of the screening method used (DGGE of genomic DNA exploring $90 \%$ of the coding sequence + flanking intronic regions), it may also reflect a sampling bias since we serve as a reference laboratory for sarcoglycanopathies.

Another important feature is the variety of different mutations; altogether we observed 25 distinct mutations out of the 62 chromosomes carrying a mutated $\alpha-S G$ gene. The relevance of the 10 different null mutations (table 2) is unquestionable. We believe that the 15 different missense mutations are also pathogenic because (1) they cosegregated in each family with the disease trait, (2) they affected conserved residues, ${ }^{1}$ and (3) they were not found on 200 control chromosomes. Very few neutral sequence variations that can be considered as polymorphisms were found (described in the Results section).

The considerable allelic heterogeneity and the wide geographical distribution of the patients carrying different haplotypes indicate that the disease results from independent mutations occurring in different populations (21 from western Europe, four from USA, six from North Africa). This is substantiated by the other cases reported in Brazil,,${ }^{19}$ USA, ${ }^{17}$ and Japan. ${ }^{18}$ This high allelic diversity was also found in the endogamic populations of North Africa (Algeria, Morocco), where in six unrelated families the patients were homozygous for six different mutations in the $\alpha$-SG gene. This indicates that in North Africa sarcoglycanopathies are genetically heterogeneous, and not solely the result of defects in the $\gamma-S G$ gene, ${ }^{15}$ as suggested by previous linkage studies. ${ }^{24-26}$

In non-endogamic western countries, $72 \%$ of the patients were compound heterozygotes. In the remaining proportion of $28 \%$ of homozygotes there was no known consanguinity. In our computation of the frequency of recurrent mutations, however, we considered the latter to be carried by two identical chromosomes derived from a founding ancestor (table 4).

Regarding the site of the mutations on the gene, we observed that exon 3 is most frequently mutated, accounting for $46 \%$ of the affected chromosomes. However, the most salient finding is that some of the missense mutations recur with a striking frequency (table 4). Because they were found in subjects from various ethnic backgrounds and with different haplotypes (data not shown) they must result from independent events. The R77C mutation is by far the most frequent mutation, accounting for $32 \%$ of the mutated chromosomes. Four out of these five recurrent mutations occur at $\mathrm{CpG}$ sites, involving codons $34,77,98$, and 284 (table 4 ). CpG sites are generally considered as the target of about one third of mutations found in human genetic diseases and tumours. ${ }^{27}$ Interestingly, out of the 
Table 6 Genotype/phenotype correlations in identical pairs of compound heterozygotes

\begin{tabular}{llllll}
\hline Genotype & Patient & Phenotype & $\begin{array}{l}a-S G \\
\text { transcripts }\end{array}$ & $a-S G$ & $\gamma$-SG \\
\hline Null + R(77)C & 6379 & Severe & nd & 0 (WB) & nd \\
Null + R(77)C & 6620 & Intermediate & nd & Traces (IF) & Traces (IF) \\
R(34)H + R(77)C & 6587 & Severe & ++ & + (WB) & + (WB) \\
R(34)H + R(77)C & 6789 & Intermediate & nd & + (IF) & ++ (IF) \\
R(77)C + R(284)C & 6487 & Sev/interm & ++ & + (WB) & ++ (WB) \\
R(77)C + R(284)C & 6556 & Moderate & ++ & $++(W B)$ & ++ (WB)
\end{tabular}

WB: western blot (normal signal $=+++$ )

IF: immunofluorescence (normal signal $=+++$ ) nd: not done

$151 \mathrm{CpG}$ sites present in the portion of the $\alpha-S G$ gene that we explored by DGGE, 50 lie in the coding region, and only four were mutated. This preference is still unexplained. It is tempting to consider it to be a result of preferential methylation, as recently discussed. ${ }^{28}$ This hypothesis was ruled out at least in the case of somatic mutations of p53. ${ }^{29}$ In our series, one in two patients (15/31) carried, at least on one chromosome, the CGC $\rightarrow$ TGC mutation in codon 77 (tables 3 and 4). This is reminiscent of other highly recurrent mutations at preferential $\mathrm{CpG}$ sites, such as in the factor $\mathrm{IX}^{30}$ and the $\beta$ cardiac myosin heavy chain genes. ${ }^{31}$ The only recurrent point mutation of our series that did not occur at a $\mathrm{CpG}$ is V247M (table 5), reminiscent of a similar GTG $\rightarrow$ ATG (V162M) observed in the factor VIII gene in 11 cases of haemophilia $A .{ }^{32}$ It is puzzling that 11 out of 13 bases around this mutated site in the factor VIII gene and in the $\alpha-S G$ gene are identical. A practical consequence of the recurrence of some mutations is the possibility of screening a large number of probands by comparison with previously identified DGGE patterns and to check each suspected mutation by restriction enzyme digestion or sequencing (table 3 ).

The gene products, transcripts, and protein were analysed, when possible, to see the molecular impact of each mutation. The mRNA level and size were normal, except in two patients harbouring splice mutations. In patient 6280 with a mutation in the donor site of exon 1, the transcript was aberrant; in patient 6141 with a mutation in the acceptor site of exon 6 , the transcript was aberrant because of the splicing of exon 5 to a cryptic acceptor site in intron 6 , resulting in a frameshift after exon 5 .

As expected in null mutations the protein was not seen (table 5). It is remarkable that, with the exception of R284C, every missense mutation results in a drastic decrease of the protein. The effect of missense mutations on the protein level is most probably posttranslational and not explained by an impact upon transcription, because whenever the transcript was studied (five cases) it was not found to be significantly decreased (table 6). Three substitutions, V175A and the neighbouring L173P in exon 5, and V247M in exon 6 (fig 1), reside precisely within a potential glycosylation site. ${ }^{1}$ Their possible impact on glycosylation was not tested. Missense mutations may also jeopardise the intrinsic stability of the $\alpha$-sarcoglycan, and in turn destabilise the whole sarcoglycan complex. ${ }^{11}$ Indeed all the missense mutations reside in the extracellular domain and have a drastic quantitative effect on the protein level, suggesting that the mutated regions are critical in the formation and stability of the sarcoglycan complex. Another possibility is that the observed missense mutations perturb those epitopes that are recognised by the antibodies used in this study, thus giving a false idea of the amount of protein. It should be noted that the complete absence of $\alpha-S G$, which is invariably associated with a severe phenotype, is accompanied either by a drastic decrease of $\gamma$-SG (case 6520 , table 5 ) or by a moderate decrease of $\gamma$-SG (case 6141 , table 5). Patient 6520 is homozygous for the R77C missense mutation, whereas patient 6141 is homozygous for a null mutation. This suggests that a mutated $\alpha-S G$ may be more deleterious to the whole complex stability than its total absence. The missense mutations observed designate candidate residues essential for the formation and stability of the complex.

The clinical presentation of 31 patients with 25 different mutations in the $\alpha$-SG gene is far from being unequivocal. The phenotypes of 15 of them are fully described by Eymard et al..$^{20}$ The problem is further complicated by the fact that affected sibs in the same family may have a different clinical course. ${ }^{5}$ To obtain a contrasting view of the clinical course we have classified the phenotypes in four simplistic but operational categories: severe for Duchenne-like (onset around age 5), intermediate for Beckerlike (onset at the age of 10-15), moderate for adult onset with disability, and benign for adult onset without disability (tables 5 and 6).

A first conclusion is that, without exception, homozygous null mutations are responsible for a severe phenotype (table 5). In two cases (table 6) a null mutation was combined with a R77C missense on the other chromosome, giving rise to an early onset disease of variable severity (Duchenne-like in patient 6379 , and Becker-like in patient 6620) (table 6). For missense mutations, correlations may be examined in homozygotes (table 5) and in compound heterozygotes bearing the same combination of alleles (table 6). In table 5 where 13 homozygous patients are classified according to the four phenotypic categories, eight cases carry a missense mutation. It appears that the R284C substitution results in a much less severe disease. The two homozygous female patients with this mutation, 57 and 29 years old respectively, only suffered from exercise intolerance (patients 6570 and 6571 described in Patients and methods section). They were biopsied on the discovery of high serum creatine kinase. Their $\alpha$-SG was moderately decreased, with little secondary impact on $\gamma$-SG (table 5). The site of this substitution is very close to the transmembrane domain, but still on the extracellular side (fig 1), and may be less critical for the integrity of the complex. The R284C mutation might be the first example of a new category of functional mutants of $\alpha-S G$ with little or no quantitative effect.

The others, R34C, R34H, and R77C, are associated with a more severe disease with 
childhood onset. There is, however, one exception in patient 6516 in whom homozygosity for $\mathrm{R} 77 \mathrm{C}$ resulted in a less severe phenotype with adult onset. Other less severely affected R77C homozygous patients have been reported in Brazil. ${ }^{19}$ For compound heterozygotes, we compared patients bearing a given allele combination (table 6). The two patients with the $\mathrm{R} 34 \mathrm{H} / \mathrm{R} 77 \mathrm{C}$ combination had a childhood onset, but they differ in the rate of progression. Two other patients with the R77C/R284C combination had different clinical courses, with childhood onset in one case and adult onset in the other (table 6).

Altogether, with the exception of the always severe null mutations and the mild R284C allele, it does not seem possible to predict a specific phenotype from the type of mutation, especially for missense mutations, suggesting the role of epistatic factors. Further observations, with detailed study of the secondary effect of each mutation on the other members of the sarcoglycan complex and other more remote sarcolemmal proteins, are needed to shed more light on the pathophysiology of sarcoglycanopathies.

We thank L V B Anderson for the supply of monoclonal anti- $\gamma-S G$ antibodies and $N$ Deburgrave and $C$ Pêcheux for their invaluable technical help. We thank D Bonneau, $O$ their invaluable technical help. We thank D Bonneau, O Nunain, and I Penisson for providing samples and clinical information from their patients. We thank J S Beckmann and H Gilmation from their patients. We thank J S Beckmann and H Gil-
genkrantz for fruitful discussion. This work was funded in part genkrantz for fruitful discussion. This work was funded in part
by the AFM (Association Française contre les Myopathies), the by the AFM (Association Française contre les Myopathies), the Assistance Publique/Hoppitaux de Paris, and the MDA. K P
Campbell is an Investigator of the Howard Hughes Medical Campbell is an Investigator of the Howard Hughes Medical
Institute. K A Azibi and F Piccolo are recipients of an AFM fel Institute.
lowship.

1 Roberds SL, Anderson RD, Ibraghimov-Beskrovnaya O, Campbell KP. Primary structure and muscle-specific expression of the $50-\mathrm{kDa}$ dystrophin-associated glycoprotein (adhalin). F Biol Chem 1993;268:23739-42.

2 Fardeau M, Matsumura K, Tomé FMS, et al. Deficiency of the $50 \mathrm{kDa}$ dystrophin associated glycoprotein (adhalin) in severe autosomal recessive muscular dystrophies in children native from European countries. C R Acad Sci III 1993;316:799-804

3 Ervasti JM, Campbell KP. Membrane organization of the dystrophin-glycoprotein complex Cell 1991:66:1121-31.

4 Yamamoto $\mathrm{H}$, Hagiwara $\mathrm{Y}$, Mizuno $\mathrm{Y}$, Yoshida $\mathrm{M}$, Heterogeneity of dystrophin-associated proteins. $\mathcal{F}$ Biochem 1993;112:132-9.

5 Ben Hamida M, Fardeau M, Attia N. Severe childhood muscular dystrophy affecting both sexes and frequent in muscular dystrophy affecting both sex
Tunisia. Muscle Nerve 1983;6:469-80.

6 Matsumura K, Tomé FMS, Collin H, et al. Deficiency of the $50 \mathrm{~K}$ dystrophin-associated glycoprotein in severe childhood autosomal recessive muscular dystrophy. Nature 1992;359:320-2

7 Bushby KMD, Beckmann JS. The limb-girdle muscular dystrophies. Proposal for a new nomenclature. Neuromus Disord 1995;5:337-43.

8 Passos-Bueno MR, Oliveira JR, Bakker E, et al. Genetic heterogeneity for Duchenne-like muscular dystrophy (DLMD) based on linkage and $50 \mathrm{DAG}$ analysis. Hum Mol Genet 1993;2:1945-7.

9 Romero NB, Tomé FMS, Leturcq F, et al. Genetic heterogeneity of severe childhood autosomal recessive muscular dystrophy with adhalin $(50 \mathrm{kDa}$ dystrophinassociated glycoprotein) deficiency. C R Acad Sci III 1994;
10 Roberds SL, Leturcq F, Allamand V, et al. Missense mutations in the adhalin gene linked to autosomal recessive muscular dystrophy. Cell 1994;78:625-33.

11 Piccolo F, Roberds SL, Jeanpierre M, et al. Primary adhalinopathy: a common cause of autosomal recessive muscular dystrophy of variable severity. Nat Genet 1995;10: 243-5.

12 Campbell KP. Adhalin gene mutations and autosomal recessive limb-girdle muscular dystrophy. Ann Neurol 1995;38:353-4

13 Bönnemann CG, Modi R, Noguchi S, et al. $\beta$-sarcoglycan (A3b) mutations cause autosomal recessive muscula dystrophy with loss of the sarcoglycan complex. Nat Genet 1995;11:266-73

14 Lim LE, Duclos F, Broux O, et al. $\beta$-sarcoglycan: characterization and role in limb-girdle muscular dystrophy linked to 4q12. Nat Genet 1995;11:257-85.

15 Noguchi S, McNally E, Ben Othmane K, et al. Mutations in the dystrophin-associated protein g-sarcoglycan in chromosome 13 muscular dystrophy. Science 1995;270:819-22.

16 Nigro V, de Sa Moreira E, Piluso G, et al. Autosomal recessive limb-girdle muscular dystrophy, LGMD2F, is caused by a mutation in the $\delta$-sarcoglycan gene. Nat Genet 1996;14:195-8

17 Ljunggren A, Duggan D, McNally E, et al. Primary adhalin deficiency as a cause of muscular dystrophy in patients with normal dystrophin. Ann Neurol 1995;38:367-72.

18 Kawai $\mathrm{H}$, Akaike $\mathrm{M}$, Endo $\mathrm{T}$, et al. Adhalin gene mutation in patients with autosomal recesssive childhood onset musin patients with autosomal recesssive childhood onset muscular dystropt

19 Passos-Bueno MR, Moreira E, Vainzof M, et al. A common missense mutation in the adhalin gene in three unrelated Brazilian families with a relatively mild form of autosoma recessive limb-girdle muscular dystrophy. Hum Mol Gene 1995;4:1163-7.

20 Eymard B, Romero NB, Leturcq F, et al. Primary adhalinopathy ( $\alpha$-sarcoglycanopathy): clinical, pathological and genetic correlation in twenty patients with autosomal recessive muscular dystrophy. Neurology (in press)

21 Fernandez E, Bienvenu T, Desclaux-Arramond F, Kaplan JC, Beldjord C. The use of chemical clamps in denaturin gradient gel electrophoresis: application in the detection of the most frequent mediterranean $\beta$-thalassemia mutation. PCR Methods \& Applications 1993;3:122-4.

22 Lerman LS, Silverstein K. Computational simulation of DNA melting and its application to denaturing gradient gel elctrophoresis. Methods Enzymol 1987;155:482-501.

23 McNally EM, Yoshida M, Mizuno Y, Ozawa E, Kunkel LM. Human adhalin is alternatively spliced and the gene is Human adhalin is alternatively spliced and the gene is
located on chromosome 17q21. Proc Natl Acad Sci USA 1994;91:9690-4.

24 Ben Othmane K, Ben Hamida M, Pericak-Vance M, et al. Linkage of Tunisian autosomal recessive Duchenne-like muscular dystrophy to the pericentromeric region of chromosome 13q. Nat Genet 1992;2:315-17.

25 Azibi K, Bachner L, Beckmann JS, et al. Severe childhood autosomal recessive muscular dystrophy with the deficiency of the $50 \mathrm{kDa}$ dystrophin-associated glycoprotein maps to chromosome 13q12. Hum Mol Genet 1993;2:14238 .

26 El Kerch F, Sefiani A, Azibi K, et al. Linkage analysis of families with severe childhood autosomal recessive muscular dystrophy (SCARMD) in Morocco indicates genetic homogeneity of the disease in North Africa. 7 Med Genet 1994;31:342-3

27 Cooper DN, Krawczak M. Human gene mutation. Vol 1. Oxford: BIOS Scientific Publications, 1993:402.

28 Sapienza C. A paternal wash in Apert syndrome. Nat Genet 1996;13:9-10

29 Tornaletti S, Pfeifer GP. Complete and tissue-independent methylation of $\mathrm{CpG}$ sites in the p53 gene: implications for methylation of $\mathrm{CpG}$ sites in the $\mathrm{p} 53$ gene: implications for
mutations in human cancers. Oncogene 1995;10:1493-9.

30 Giannelli F, Green PM, Sommer SS, et al. Haemophilia B database of point mutations and short additions and deletions, fifth edition, 1994. Nucleic Acids Res 1994;22:353446

31 Watkins H, Seidman JG, Seidman CE. Familial hypertrophic cardiomyopathy: a genetic model of cardiac hypertrophy. Hum Mol Genet 1995;4:1721-7.

32 Wacey AI, Kemball CG, Kazazian $\mathrm{HH}$, et al. The haemophilia A mutation search test and resource site, home page of the factor VIII mutation database: HAM STERS. Nucleic Acids Res 1996;24:100-2. 